\title{
Nanoscale Zero-Valent Iron and Chitosan Functionalized Eichhornia crassipes Biochar for Efficient Hexavalent Chromium Removal
}

\author{
Xue-Li Chen ${ }^{1}$, Feng Li ${ }^{1}{ }^{1 *}$, Xiao Jie Xie ${ }^{1}$, Zhi Li ${ }^{2}$ and Long Chen ${ }^{3, *}$ \\ 1 School of Civil Engineering \& Transportation, South China University of Technology, \\ Guangzhou 510640, China \\ 2 San Bernardino, California State University, San Bernardino, CA 92407, USA \\ 3 Department of Civil and Environmental Engineering, Northeastern University, Boston, MA 02115, USA \\ * Correspondence: hjlifeng@scut.edu.cn (F.L.); lo.chen@northeastern.edu (L.C.)
}

Received: 9 July 2019; Accepted: 19 August 2019; Published: 22 August 2019

\begin{abstract}
Sorption is widely used for the removal of toxic heavy metals such as hexavalent chromium $(\mathrm{Cr}(\mathrm{VI}))$ from aqueous solutions. Green sorbents prepared from biomass are attractive, because they leverage the value of waste biomass and reduce the overall cost of water treatment. In this study, we fabricated biochar (BC) adsorbent from the biomass of water hyacinth (Eichhornia crassipes), an invasive species in many river channels. Pristine $B C$ was further modified with nanoscale zero-valent iron (nZVI) and stabilized with chitosan (C) to form C-nZVI-BC. C-nZVI-BC adsorbent showed high hexavalent chromium sorption capacity $(82.2 \mathrm{mg} / \mathrm{g})$ at $\mathrm{pH} 2$ and removed $97.34 \%$ of $50 \mathrm{mg} / \mathrm{L} \mathrm{Cr}(\mathrm{VI})$ from aqueous solutions. The sorption capacity of chitosan-nZVI-modified biochar decreased while increasing the solution $\mathrm{pH}$ value and ionic strength. The results of a sorption test indicated that multiple mechanisms accounted for $\mathrm{Cr}(\mathrm{VI})$ removal by $\mathrm{C}-\mathrm{nZVI}-\mathrm{BC}$, including complexation, precipitation, electrostatic interactions, and reduction. Our study suggests a way of adding value to biomass waste by considering environmental treatment purposes.
\end{abstract}

Keywords: chromium; biochar; nanoscale zero-valent iron; chitosan; sorption

\section{Introduction}

Chromium ( $\mathrm{Cr}$ ) is widely used in corrosion-resistant material and inorganic pigments [1,2], and the improper release of $\mathrm{Cr}$ has caused severe environmental pollution [3-5]. The $\mathrm{Cr}$ ion has two valences, i.e., the trivalent $\mathrm{Cr}(\mathrm{III})$ and hexavalent $\mathrm{Cr}(\mathrm{VI})$ valences. Compared to $\mathrm{Cr}(\mathrm{III}), \mathrm{Cr}(\mathrm{VI})$ shows higher acute toxicity and has been categorized as a carcinogenic substance by the U.S. Agency for Toxic Substances and Diseases Registry (ATSDR) [6]. Moreover, $\mathrm{Cr}(\mathrm{VI})$ is stable in complicated water chemistry and is soluble over a wide $\mathrm{pH}$ range [2,4,7], leading to severe health concerns.

Sorption has been demonstrated as an economic and effective way to remove many toxic compounds and ions, mainly because the overall process is easy to operate and no secondary contaminants are generated [8-13]. For the past few decades, various sorbents have been developed, including activated carbon [8], clay minerals [9], metal-organic frameworks [11], and two-dimensional nanomaterials $[10,13]$. Recently, an amorphous and porous carbon material produced from the pyrolysis of biomass, named biochar, has shown strong potential in environmental remediation [12,14,15]. For example, biochars prepared from soybean stalks [16], bamboo and rice straw [17], and sugarcane bagasse [18] were used to remove various heavy metals from aqueous solution, with remarkable efficiencies comparable to activated carbon [8]. The most significant advantages of biochar as an adsorbent are low costs, its abundancy as a raw material, and easiness to produce $[12,14]$. 
Water hyacinth (Eichhornia crassipes) is an exotic plant that has invaded many rivers around the world, and the uncontrolled growth causes safety issues to the sailing industry and ecological concerns to local fisheries [19-21]. The harvested E. crassipes biomass requires complicated deposition steps for treatment [20]. The conversion of E. crassipes biomass into an adsorbent is a sustainable strategy to simultaneously address biomass deposition and environmental pollution [22-27]. Due to its rapid growth, E. crassipes biomass is relatively simple in composition, which enables its pyrolysis into biochar [23-26]. However, pristine biochar usually owns unsatisfactory sorption capability, and further modifications are needed [14,28]. The loading of nanoscale zero-valent irons (nZVIs) on the biochar surface is an effective way to enhance heavy metal removal, based on reported synergy mechanisms including reduction, electrostatic attraction, and sorption $[3,29,30]$. In addition, cation exchange resin-supported nano-iron materials also have been used for the treatment of $\mathrm{Cr}(\mathrm{VI})$-contaminated groundwater [31]. However, the major challenges of nZVI modification include agglomeration due to magnetic attraction and oxidation after exposure to air [3]. It has been reported that nZVI could be stabilized by assembling multiple-layer materials. For example, chitosan is able to complex with nZVI and reduce interparticular attractions.

In this work, a multilayered chitosan-nZVI-modified biochar (C-nZVI-BC) was prepared via sequentially growing nZVI particles and adding chitosan-stabilizing agent to pristine $B C$. The C-nZVI-BC composite showed high sorption efficiency toward $\mathrm{Cr}(\mathrm{VI})$. The structure, morphology, compositional distribution, and element chemical states of C-nZVI-BC were extensively characterized using X-ray diffraction (XRD), scanning electron microscopy (SEM), energy-dispersive $X$-ray spectroscopy (EDS), and X-ray photoelectron spectroscopy (XPS). A synergy of multiple mechanisms is proposed to account for the excellent $\mathrm{Cr}(\mathrm{VI})$ removal efficiency in our study. Our study suggests modification strategies for future biochar design based on revealed mechanisms.

\section{Materials and Methods}

\subsection{Materials}

Fresh E. crassipes biomasses were collected from a stream in Nansha district, Guangzhou, China. Hexavalent chromium standard solution was purchased from Beijing Aike Yingchuang Chemical Reagent Co., Ltd., China (standard substances network). Other chemicals, including $\mathrm{FeSO}_{4} \cdot 7 \mathrm{H}_{2} \mathrm{O}$ (99\%, analytical reagent grade), polyethylene glycol (PEG-4000, guaranteed reagent grade), $\mathrm{NaBH}_{4}$ ( $98 \%$, analytical reagent grade), chitosan $(90 \%$, guaranteed reagent grade), glutaraldehyde ( $25 \%$, guaranteed reagent grade), $\mathrm{NaOH}$, acetic acid, anhydrous ethanol, and hydrochloric acid were of analytical reagent grade from Tansoole Chemical Technology (Shanghai, China) and were used as received without further purification.

\subsection{Preparation of Adsorbents}

\subsubsection{Preparation of Pristine Biochar (BC)}

The E. crassipes biomasses were cleaned, cut into 5 -cm pieces, and then dried at $95{ }^{\circ} \mathrm{C}$. The dried biomasses ( $300 \mathrm{~g}$ ) were heated to $400{ }^{\circ} \mathrm{C}$ in a pipe furnace with nitrogen as the fluidizing gas at a rate of $1.5 \mathrm{~L} / \mathrm{min}$ and then held for $3 \mathrm{~h}$. In order to remove the ash of biochar, the biochar was soaked in $25 \% \mathrm{HCl}$ for $12 \mathrm{~h}$ with stirring. The biochar was subsequently washed with alcohol and deionized water each for three times and then dried in an oven at $95^{\circ} \mathrm{C}$. The obtained biochar was grounded and sieved to $0.5 \sim 1-\mathrm{mm}$-sized particles for future use. The resulting biochar was referred to as BC.

\subsubsection{Preparation of nZVI-BC Composite}

Under a nitrogen atmosphere, $\mathrm{FeSO}_{4} \cdot 7 \mathrm{H}_{2} \mathrm{O}(1.0 \mathrm{mmol}, 287 \mathrm{mg})$, polyethylene glycol (PEG-4000, $0.5 \mathrm{~g})$ dispersant, and $\mathrm{BC}(6 \mathrm{~g})$ were added to $70 \%$ aqueous ethanol $(200 \mathrm{~mL})$ and stirred at room temperature for $3 \mathrm{~h}$. Then, $\mathrm{NaBH}_{4}$ solution $(50 \mathrm{~mL}$ at $0.4 \mathrm{~mol} / \mathrm{L})$ was added dropwise into the above 
slurry and was kept stirred at room temperature for $1 \mathrm{~h}$. Black powder was subsequently collected by filtration and then washed three times with deionized water and anhydrous ethanol. The pellets were then vacuum-dried at $-25^{\circ} \mathrm{C}$ for $24 \mathrm{~h}$. The obtained product was sieved through $0.5 \sim 1-\mathrm{mm}$ screens and stored for further use. The resulting material was labeled as nZVI-BC.

\subsubsection{Preparation of C-nZVI-BC Composite}

Here, $3 \mathrm{~g}$ chitosan was dissolved in $200 \mathrm{~mL}$ diluted acetic acid solution $(2 \%, \mathrm{v} / \mathrm{v})$. After the addition of $3 \mathrm{~g}$ nZVI-BC into the above solution, it was heated to $30^{\circ} \mathrm{C}$ and stirred for $2 \mathrm{~h}$, followed by the dropwise addition of $80 \mathrm{~mL}$ glutaraldehyde $(2.5 \%, \mathrm{v} / \mathrm{v})$. Then the mixture was stirred for $1 \mathrm{~h}$ at $40^{\circ} \mathrm{C}$. $\mathrm{NaOH}$ solution was added dropwise until the $\mathrm{pH}$ value reached 9 and was stirred for another $0.5 \mathrm{~h}$ at room temperature. Black powder was collected by filtration, washed three times with deionized water, and vacuum-dried at $-25^{\circ} \mathrm{C}$ for $24 \mathrm{~h}$. The resulting material was referred to as C-nZVI-BC (Figure 1).

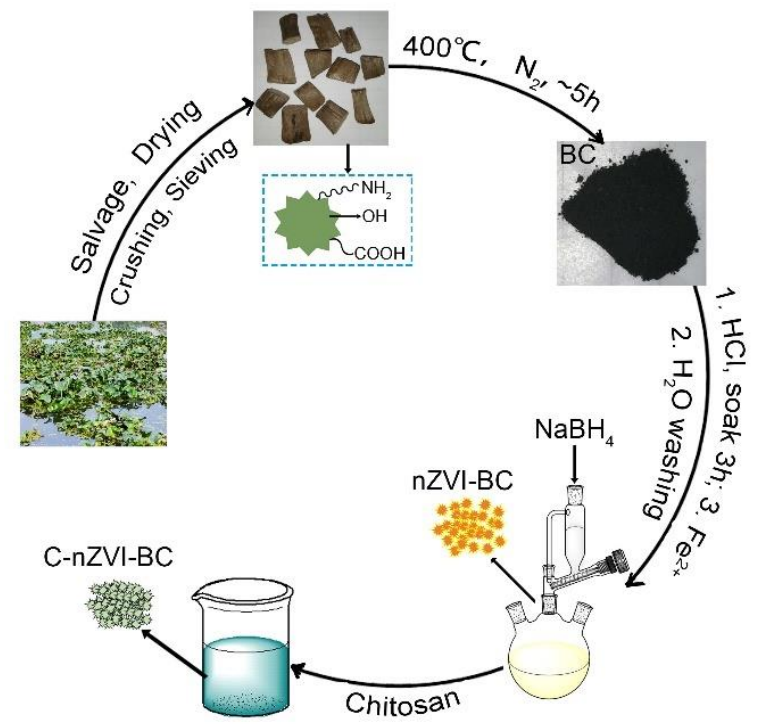

Figure 1. A scheme showing the process of the production of biochar (BC), nanoscale zero-valent ion (nZVI)-BC, and chitosan (C)-nZVI-BC.

\subsection{Characterizations}

FTIR spectra were recorded on a Bruker Vector 33 spectrophotometer in the range $4000-400 \mathrm{~cm}^{-1}$. Samples were dried and then mixed with $\mathrm{KBr}$ followed by compression. Powder X-ray diffraction (PXRD) intensities were measured on a Rigaku D/max-IIIA diffractometer $(\mathrm{Cu} \mathrm{K} \alpha)$ at $298 \mathrm{~K}$. The samples were placed on a grooved aluminum plate, and patterns were recorded from $3^{\circ}$ to $60^{\circ}$ at a rate of $15^{\circ} / \mathrm{min}$. The obtained XRD patterns were analyzed with PDXL software after removal of the background radiation. The thermal properties were measured using a gravimetric analyzer (Netzsch TG 209 F1) under a constant flow of dry nitrogen gas at a rate of $5{ }^{\circ} \mathrm{C} / \mathrm{min}$. An $\mathrm{N}_{2}$ adsorption isotherm was performed with an automatic volumetric adsorption apparatus (Autosorb-iQ, Quantachrome) at 77 $\mathrm{K}$. To understand the surface characteristics and compositional distribution analysis of adsorbents, the adsorbents were studied by scanning electron microscopy combined with energy dispersive X-ray spectroscopy (SEM-EDS) (LEO1530VP, ZEISS). Samples were coated with a thin film of platinum and then imaged using a field emission operating at $20 \mathrm{keV}$. Cr element analysis was conducted after final dilution $\left(0.1 \% \mathrm{HNO}_{3}\right.$ : sample $\left.=1: 5\right)$ by inductively coupled plasma atomic emission spectrometry (ICP-AES) (Perkin Elmer Plasma 3200Rl). X-ray photoelectron spectroscopy (XPS) spectra were performed in a Kratos Axis ultra (DLD) spectrometer equipped with an Al K $\alpha$ X-ray source in ultrahigh vacuum (UHV; $<10^{-10}$ Torr). The surfaces of samples were cleaned by heat treatment at $100{ }^{\circ} \mathrm{C}$ in an UHV prior to the measurements. 


\subsection{Sorption Experiments}

Batch experiments were conducted to evaluate the sorption capacity of the BC, nZVI-BC, and C-nZVI-BC. Additionally, the factors that influence sorption performance, such as the sorption time, the $\mathrm{pH}$ value, the concentration of the hexavalent chromium solution, and ionic strength, were discussed. Solutions with different $\mathrm{Cr}(\mathrm{VI})$ concentrations were prepared $(50,100$, and $200 \mathrm{mg} / \mathrm{L})$. The initial $\mathrm{pH}$ value of the solution was adjusted by using $\mathrm{HNO}_{3}(0.1 \mathrm{M})$ and $\mathrm{NaOH}(0.1 \mathrm{M})$ aqueous solution. The optimal sorption conditions were discussed, and the specific values of the variable are listed in Table S1.

In all experiments, the vials were agitated on a reciprocating shaker $(160 \mathrm{rpm})$ at $30{ }^{\circ} \mathrm{C}$ for $24 \mathrm{~h}$. The mixture suspensions were separated by centrifugation ( $4000 \mathrm{rpm}$ ) for $15 \mathrm{~min}$. Afterwards, the adsorbents were filtered through $0.45-\mu \mathrm{m}$ pore size filters (GE cellulose nylon membrane). The $10-\mathrm{mL}$ filtrate was then treated with $2 \mathrm{~mL} 0.1 \% \mathrm{HNO}_{3}$ solution, and $\mathrm{Cr}(\mathrm{VI})$ concentrations were analyzed. $\mathrm{Cr}(\mathrm{VI})$ concentrations were determined via inductively coupled plasma atomic emission spectrometry (ICP-AES). The $\mathrm{Cr}(\mathrm{VI})$ removal was calculated from the initial minus the final aqueous concentrations. All experiments were carried out in duplicate.

Isotherm experiments were conducted by mixing $1 \mathrm{~g} / \mathrm{L}$ adsorbent with $\mathrm{Cr}(\mathrm{VI})$ concentrations ranging from 0 to $160 \mathrm{mg} / \mathrm{L}$ at $30^{\circ} \mathrm{C}$ for $24 \mathrm{~h}$. Langmuir and Freundlich models were used to fit the sorption isotherm data $[32,33]$. The equations for these models are as follows.

Langmuir model equation:

$$
\frac{C_{e}}{Q_{e}}=\frac{1}{K_{L} Q_{m}}+\frac{C_{e}}{Q_{m}}
$$

Freundlich model equation:

$$
\ln Q_{e}=\ln K_{f}+N \ln C_{e}
$$

where $C_{e}=$ equilibrium concentration $(\mathrm{mg} / \mathrm{L}) ; Q_{e}=$ equilibrium sorption capacity $(\mathrm{mg} / \mathrm{g}) ; Q_{m}=$ maximum sorption capacity $(\mathrm{mg} / \mathrm{g}) ; K_{L}=$ Langmuir model parameter $(\mathrm{L} / \mathrm{mg}) ; K_{f}=$ Freundlich model parameter $\left(\mathrm{mg}^{(1-\mathrm{n})} \cdot \mathrm{L}^{\mathrm{n}} / \mathrm{g}\right)$; and $n=$ sorption intensity.

Kinetic experiments were studied at different time intervals $(0,10,30,60,120,240,480,720,1080$, and $1440 \mathrm{~min}$ ) at $30^{\circ} \mathrm{C}$. In each study, $100 \mathrm{mg}$ of adsorbates was added to $100 \mathrm{~mL}$ of $\mathrm{Cr}$ (VI) solution $(100 \mathrm{mg} / \mathrm{L})$. Three kinetic models were used to fit the sorption kinetics data [32,33]. The equations for these models are as follows.

Pseudo-first-order model equation:

$$
\log \left(q_{e}-q_{t}\right)=\log q_{e}-\frac{k_{1}}{2.303} t
$$

Pseudo-second-order model equation:

$$
\frac{t}{q_{t}}=\frac{t}{q_{e}}+\frac{1}{k_{2} q_{e}^{2}}
$$

Elovich equation:

$$
\frac{d q_{t}}{d t}=\alpha \exp \left(-\beta q_{t}\right)
$$

where $q_{e}=$ equilibrium sorption $(\mathrm{mg} / \mathrm{g}) ; q_{t}=$ time $t$ sorption $(\mathrm{mg} / \mathrm{g}) ; k_{1}=$ rate constant of the pseudo-first-order $(1 / \mathrm{min})$ model; $k_{2}=$ rate constant of the pseudo-second-order $(\mathrm{g} /(\mathrm{mg} \cdot \mathrm{min}))$ model; $\alpha=$ initial sorption rate $(\mathrm{mg} /(\mathrm{g} \cdot \mathrm{min}))$; and $\beta=$ desorption rate $(\mathrm{g} / \mathrm{mg})$.

\subsection{Regeneration of $C-n Z V I-B C$ Adsorbent}

In addition, the reusability of the synthesized C-nZVI-BC was tested through sorption-desorption assays: $100 \mathrm{mg} \mathrm{C-nZVI-BC}$ was added into $100 \mathrm{~mL} \mathrm{Cr}(\mathrm{VI})$ solution $(100 \mathrm{mg} / \mathrm{L})$. After agitation (160 rpm) at $30^{\circ} \mathrm{C}$ for $24.0 \mathrm{~h}$, the $\mathrm{Cr}(\mathrm{VI})$-loaded C-nZVI-BC adsorbent particles were separated from 
the suspensions by centrifugation at $4000 \mathrm{rpm}$ for $15 \mathrm{~min}$. After each experiment, the adsorbent was washed thoroughly with desorption reagent $\left(0.1 \mathrm{M} \mathrm{HNO}_{3}\right)$ followed by treatment with deionized water to remove the adsorbed $\mathrm{Cr}$ ions and was eventually dried at $80^{\circ} \mathrm{C}$. The regenerated C-nZVI-BC was reused in sorption experiments with the same procedure as described above.

\section{Results and Discussion}

\subsection{Characterization of Adsorbents}

Our strategy for the synthesis of the chitosan-nZVI-modified biochar (C-nZVI-BC) is described in Figure 1. First, the thermal stability and components of the BC, nZVI-BC, and C-nZVI-BC were analyzed by using thermogravimetric analysis (TGA). The pristine $\mathrm{BC}$ was stable below $400{ }^{\circ} \mathrm{C}$, which indicated the transformation from biomass to biochar. From $400{ }^{\circ} \mathrm{C}$ to $600{ }^{\circ} \mathrm{C}$, the biochar underwent severe weight losses, which could be a continuous carbonization process (Figure S1a). By comparison, the weight loss rate of nZVI-biochar was 5.35\%, and C-nZVI-BC was $6.42 \%$ at $\sim 200{ }^{\circ} \mathrm{C}$ (Figure S1), which were ascribed to the adsorbed water molecules. Moreover, the TGA curve of C-nZVI-BC revealed two weight loss regions at approximately $204 \sim 416^{\circ} \mathrm{C}$ and $416 \sim 545{ }^{\circ} \mathrm{C}$, which could be attributed to the decomposition of chitosan [34] and the transformation of residual cellulose into biochar (Figure S1c), respectively. The pristine BC exhibited less residual mass (ca. 8.7\%) than nZVI-BC and C-nZVI-BC when the temperature reached $800{ }^{\circ} \mathrm{C}$ (Figure S1) due to the presence of iron species in nZVI-BC and C-nZVI-BC.

In order to assess the surface areas and pore volumes of the BC, nZVI-BC, and C-nZVI-BC, we performed $\mathrm{N}_{2}$ adsorption-desorption experiments (Table S2). The surface area for BC, nZVI-BC, and C-nZVI-BC was $512.89,748.99$, and $833.10 \mathrm{~m}^{2} / \mathrm{g}$, respectively. The pore volume showed a very slight variation for these three biochars, ranging from $0.46 \mathrm{~cm}^{3} / \mathrm{g}$ to $0.61 \mathrm{~cm}^{3} / \mathrm{g}$. Overall, these results indicated that the biochar surface property profoundly changed after loading nZVI and chitosan.

The X-ray diffraction pattern (XRD) was used to study the phase structure of the BC, nZVI-BC, and C-nZVI-BC. As shown in Figure 2a, the XRD pattern of pristine BC showed a wide diffraction peak at $24.3^{\circ}$, which might have arisen from an amorphous carbon phase structure [12,14]. The XRD pattern of the $\mathrm{nZVI-BC}$ showed a series of diffraction peaks in the range of $10 \sim 60^{\circ}$ (Figure 2a). The peaks at $42.2^{\circ}, 44.9^{\circ}$, and $49.7^{\circ}$ indicated the presence of zerovalent iron (JCPDS, No. 06-0696). The characteristic diffraction peaks at $20.3^{\circ}$ and $22.6^{\circ}$ belonged to $\mathrm{FeO}(\mathrm{OH})$ [34]. The characteristic diffraction peaks at $31.8^{\circ}, 37.8^{\circ}, 38.5^{\circ}, 41.2^{\circ}$, and $52.4^{\circ}$ belonged to $\mathrm{Fe}_{3} \mathrm{C}$ [35]. The rest of the diffraction peaks at $39.7^{\circ}$, $15.5^{\circ}, 35.1^{\circ}$, and $18.1^{\circ}$ corresponded to $\mathrm{FeO}$ (JCPDS, No. 33-0664), $\mathrm{Fe}_{2} \mathrm{O}_{3}$ (JCPDS, No. 39-1346), and $\mathrm{Fe}_{3} \mathrm{O}_{4}$ (JCPDS, No. 19-0629), respectively. The results indicated that nZVI nanoparticles were easily oxidized on the biochar surface, likely because of exposure to atmosphere during the drying process and the fast redox response of iron species [36]. The preparation of C-nZVI-BC could possibly avoid the oxidation of surface nZVI particles, because chitosan is viewed as a stabilizer for reducing agents $[3,24,27,29,37]$. The XRD pattern for the C-nZVI-BC showed a wide diffraction peak at $27.4^{\circ}$ : the broad and low-intensity nature of the peak indicated that the C-nZVI-BC had an amorphous structure (Figure 2a). These results indicated that nZVI particles were successfully loaded onto the surface of the E. crassipes-derived biochar with chitosan to form a multiple-layer composite.

The surface functional groups of BC, nZVI-BC, and C-nZVI-BC were investigated with FTIR spectra (Figure 2b). The absorption band at $3200 \sim 3600 \mathrm{~cm}^{-1}$ was due to the $\mathrm{O}-\mathrm{H}$ and $\mathrm{N}-\mathrm{H}$ groups stretching vibrations. Compared to pristine $\mathrm{BC}$, it was observed that the stretching vibrations of $-\mathrm{OH}$ in modified BCs (i.e., nZVI-BC and C-nZVI-BC) were significantly stronger, indicating that modified $\mathrm{BC}$ s owned more -OH groups, possibly from adsorbed water and chitosan. In addition, the new characteristic peak at about $1376 \mathrm{~cm}^{-1}$ for C-nZVI-BC belonged to the stretching vibration of $\mathrm{N}-\mathrm{O}$, indicating chitosan was successfully loaded onto the nZVI-BC surface $[27,37]$. The rest of the characteristic peaks, at about 2923, 2870,1623,1441, 1235, and $1088 \mathrm{~cm}^{-1}$, were attributed to the 
stretching vibrations of $\mathrm{C}-\mathrm{H}$ (aliphatic), $\mathrm{C}=\mathrm{C}$ (aromatic), $\mathrm{COOH}$, or $\mathrm{C}-\mathrm{N} / \mathrm{O}$ groups, indicating the multifarious diversity of functional groups on the $\mathrm{C}-\mathrm{nZVI}-\mathrm{BC}$ surface.

An X-ray photoelectron spectroscopy (XPS) analysis was utilized to analyze the surface chemical composition of BC, nZVI-BC, and C-nZVI-BC. The X-ray photoelectron spectra of pristine BC (Figure S2, line i) revealed the presence of $\mathrm{C} 1 \mathrm{~s}(284.9 \mathrm{eV}), \mathrm{N} 1 \mathrm{~s}(400.4 \mathrm{eV})$, and $\mathrm{O} 1 \mathrm{~s}(532.1 \mathrm{eV})$ on the BC surface without an iron element. The spectra for the nZVI-BC and C-nZVI-BC (Figure S2, line ii and line iii) showed the peaks of $\mathrm{C} 1 \mathrm{~s}, \mathrm{~N} 1 \mathrm{~s}, \mathrm{O} 1 \mathrm{~s}$, and Fe $2 \mathrm{p}$ (ranging from 702 to $730 \mathrm{eV}$ ). The $\mathrm{O} 1 \mathrm{~s}$ peaks were then deconvoluted into several fine peaks for a detailed study. Two peaks were found in the $\mathrm{O}$ 1s spectrum of pristine $\mathrm{BC}$, which corresponded to $\mathrm{C}=\mathrm{O}$ and $\mathrm{C}-\mathrm{OH}$ groups at 531.21 and $532.93 \mathrm{eV}$ (Figure 2d) [38]. Compared to pristine BC, a remarkable change was observed in the $\mathrm{O} 1 \mathrm{~s}$ spectra of both nZVI-BC and C-nZVI-BC. For example, the O 1s spectra of nZVI-BC showed peaks at 532.24, 532.58 , and $536.99 \mathrm{eV}$, which were assigned to the $\mathrm{C}=\mathrm{O}, \mathrm{C}-\mathrm{O}-\mathrm{R}$, and $\mathrm{Fe}-\mathrm{O}$ bond [37,39], respectively (Figure 2e). Moreover, the peaks at 529.36, 530.47, 531.00, and $532.54 \mathrm{eV}$ indicated the $\mathrm{Fe}-\mathrm{O}-\mathrm{Fe}, \mathrm{Fe}-\mathrm{O}$, $\mathrm{C}=\mathrm{O}$, and $\mathrm{C}-\mathrm{O}-\mathrm{R}$ bonds on the $\mathrm{C}-\mathrm{nZVI}-\mathrm{BC}$ surface [37-39], respectively (Figure 2f). In addition, slight shifts of the peaks for the $\mathrm{C}=\mathrm{O}$ and $\mathrm{C}-\mathrm{OH}$ bonds were observed due to the modification on the biochar (Figure $2 \mathrm{~d}-\mathrm{f}$ ). Figure $2 \mathrm{c}$ shows the deconvolution of Fe $2 \mathrm{p}$ peaks. The high-resolution XPS Fe $2 \mathrm{p}$ spectrum of the nZVI-BC composite exhibited two peaks with binding energies at 711.52 and $725.12 \mathrm{eV}$, which could be assigned to $\mathrm{Fe}^{3+} 2 \mathrm{p}_{3 / 2}$ and $\mathrm{Fe}^{3+} 2 \mathrm{p}_{1 / 2}$ [40], respectively. The absence of the nZVI peak suggested that nZVI on the nZVI-BC surface was transformed into iron oxide. However, with chitosan loaded on the nZVI-BC surface, the Fe 2p spectrum of the C-nZVI-BC composite exhibited two peaks with binding energies at 706.48 and $720.02 \mathrm{eV}$, which could be assigned to $\mathrm{Fe} 2 \mathrm{p}_{3}$ and $\mathrm{Fe}^{3+}$ satellite [41], respectively. The typical peak at $706.48 \mathrm{eV}$ indicated the zero-valent iron phase, demonstrating that chitosan stabilizer could inhibit nZVI oxidation. In summary, these results indicated that the desired Fe elements species were observed on the modified biochar surface.

(a)

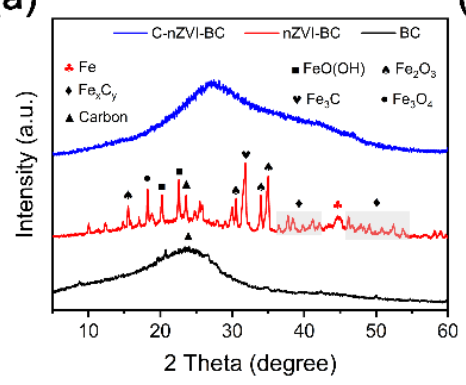

(d)

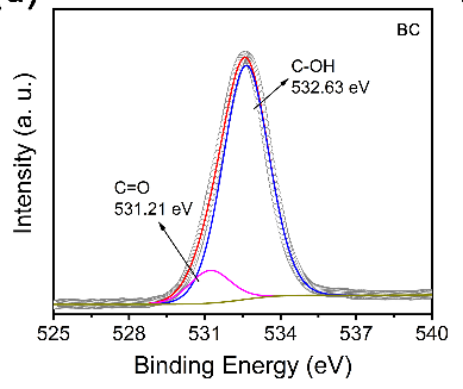

(b)

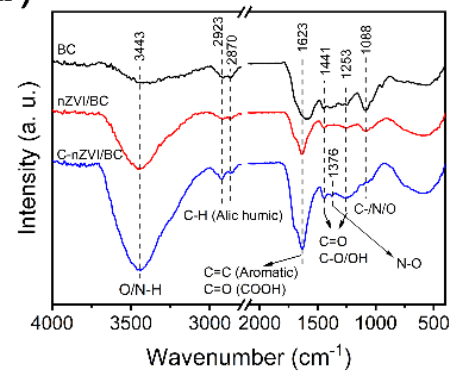

(e)

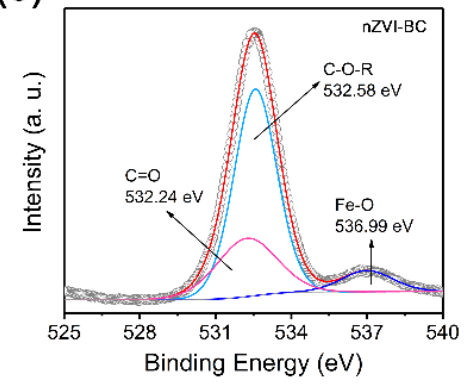

(c)

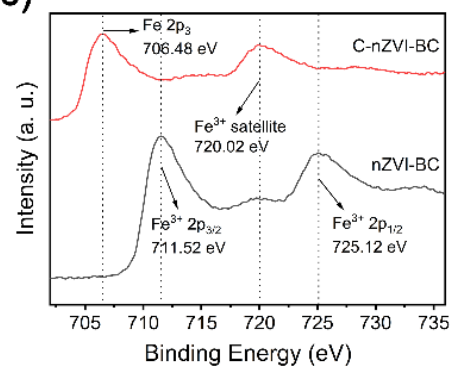

(f)

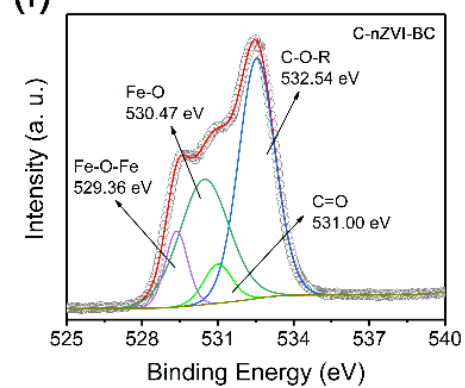

Figure 2. Characterization of BC, nZVI-BC, and C-nZVI-BC. Powder X-ray diffraction (PXRD) patterns (a); FTIR spectra (b); high-resolution X-ray photoelectron spectroscopy (XPS) spectra of Fe 2p for nZVI-BC and C-nZVI-BC (c); high-resolution XPS spectra of O 1s for BC, nZVI-BC, and C-nZVI-BC (d-f).

The morphology and compositional distributions of BC, nZVI-BC, and C-nZVI-BC were studied with SEM-EDS analysis. As shown in Figure 3, pristine BC had a relatively smooth surface (Figure 3a). After the nZVI modification, several relatively large nanoparticles were observed on the surface of the 
biochar (Figure 3b), which might have been due to magnetic interaction between iron particles [42]. The surface of C-nZVI-BC was relatively irregular and compact, but no large particles were observed with high-magnification SEM images (Figure 3c). Additionally, the elemental compositions in BC, nZVI-BC, and C-nZVI-BC were examined with SEM-EDS. For all three biochars, carbon and oxygen were uniformly distributed. An Fe signal was detected in the nZVI-BC and C-nZVI-BC (Figure $3 \mathrm{e}, \mathrm{f}$ ), but the Fe distribution on the C-nZVI-BC surface was relatively more uniform than that of nZVI-BC, suggesting that the introduction of chitosan could hinder the aggregation of nZVI particles. The SEM-EDS analysis showed that stabilizing using chitosan was a successful strategy to avoid nZVI aggregation.

(a)

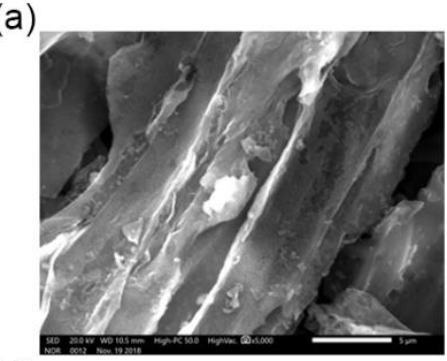

(d)

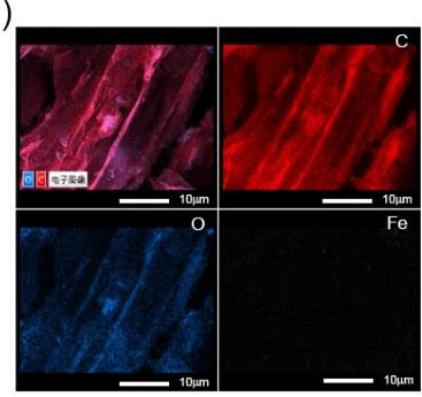

(b)

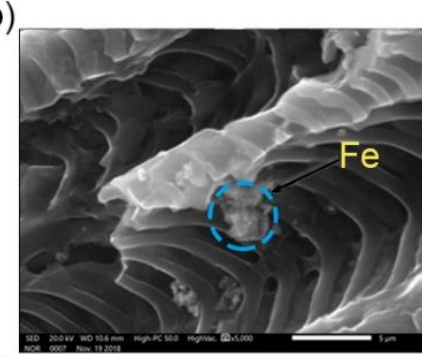

(e)

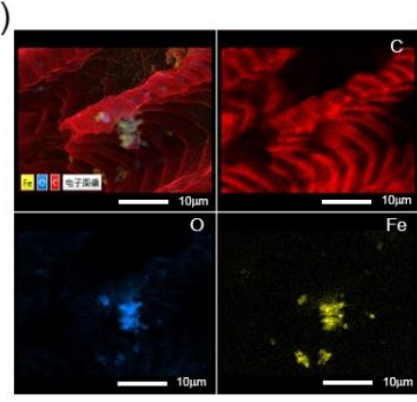

(c)

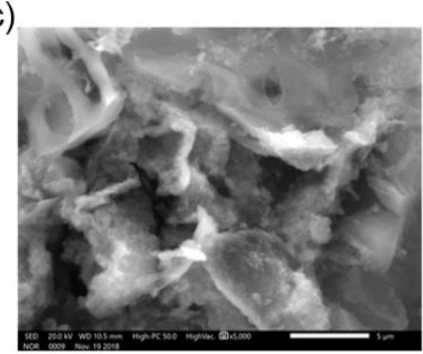

(f)

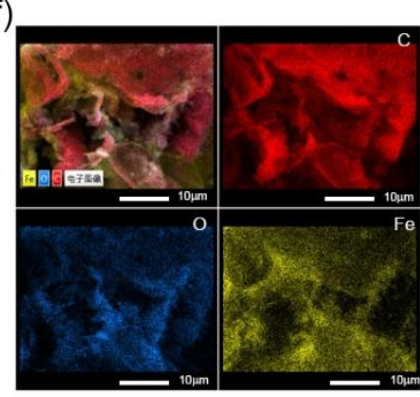

Figure 3. SEM microscopic images of as-prepared BC (a), nZVI-BC (b), and C-nZVI-BC (c). Scale bar $=5 \mu \mathrm{m}$. The element mapping indicated a distribution information of Fe (yellow), $\mathrm{O}$ (blue), and $\mathrm{C}$ (red) of the corresponding BC (d), nZVI-BC (e), and C-nZVI-BC (f). Scale bar: $10 \mu \mathrm{m}$.

\subsection{Removal of $\mathrm{Cr}(\mathrm{VI})$ by Three Biochar Adsorbents}

\subsubsection{Effect of Solution $\mathrm{pH}$}

The variation of solution $\mathrm{pH}$ could significantly influence the speciation of $\mathrm{Cr}(\mathrm{VI})$ and the electronegativity of adsorbents. When the $\mathrm{pH}$ is less than $6.8, \mathrm{HCrO}_{4}{ }^{-}$becomes the major speciation that shows certain oxidation ability, but $\mathrm{CrO}_{4}{ }^{2-}$ dominates at $\mathrm{pH}>6.8$ [5]. In addition, the zeta-potential of $\mathrm{C}-\mathrm{nZVI}-\mathrm{BC}$ was investigated under different $\mathrm{pH}$ values (Figure $4 \mathrm{a}$ ), and the isoelectric point was located at $\mathrm{pH}$ 3.47. Furthermore, the $\mathrm{pH}$-dependent $\mathrm{Cr}(\mathrm{VI})$ sorption performances for $\mathrm{BC}$, nZVI-BC, and $\mathrm{C}-\mathrm{nZVI}-\mathrm{BC}$ were examined in a $\mathrm{pH}$ value range of $2 \sim 8$. With the increase of the initial $\mathrm{pH}$ values from 2 to 8 , the sorption capacity of $\mathrm{Cr}(\mathrm{VI})$ significantly decreased from 82.2 to $19.8 \mathrm{mg} / \mathrm{g}$ in C-nZVI-BC, from 60.2 to $20.3 \mathrm{mg} / \mathrm{g}$ in nZVI-BC, and from 20.6 to $4.6 \mathrm{mg} / \mathrm{g}$ in BC (Figure $4 \mathrm{~b}$ ). Consequently, the sorption performance of the three biochars was optimal at lower $\mathrm{pH}$ values, mainly due to the protonation of functional groups on adsorbents that could enhance electrostatic attraction for $\mathrm{Cr}(\mathrm{VI})$ ions. At high $\mathrm{pH}$ values, the electrostatic repulsion among $\mathrm{CrO}_{4}{ }^{2-}, \mathrm{OH}^{-}$, and the negatively charged layer of adsorbents impeded $\mathrm{Cr}(\mathrm{VI})$ sorption. In addition, the sorption capacity and the corresponding sorption rate of C-nZVI-BC were obviously higher than those of BC and nZVI-BC (Figure $4 \mathrm{~b})$. This was because chitosan could provide more coordinating hetero atoms $(-\mathrm{OH},-\mathrm{NH})$ in the C-nZVI-BC composite, which facilitated the sorption of $\mathrm{Cr}(\mathrm{VI})$ ions [43,44]. In addition, herein, the sorption properties of various biomass feedstock biochars and Eichhornia crassipes biochars are 
compared in Table S7. Obviously, Eichhornia crassipes biochar had a great advantage in the sorption of $\mathrm{Cr}(\mathrm{VI})$.

(a)

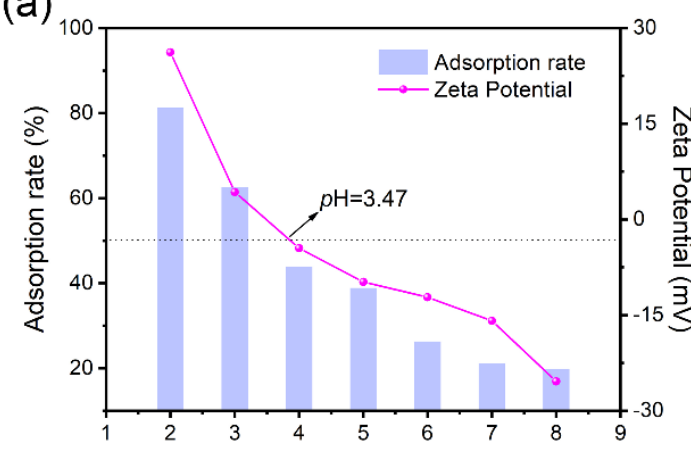

(c)

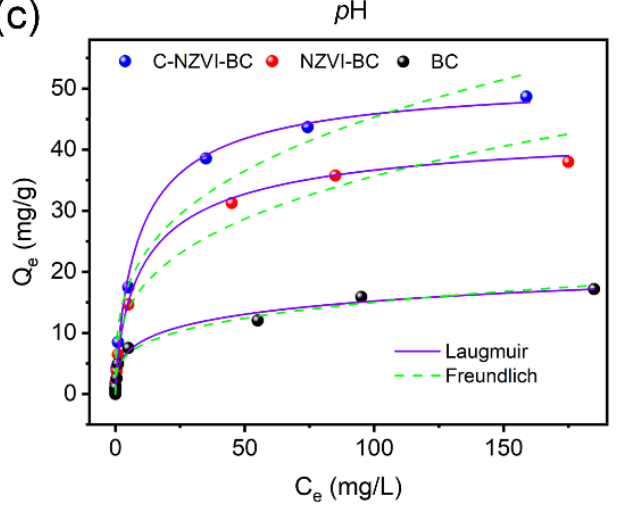

(b)

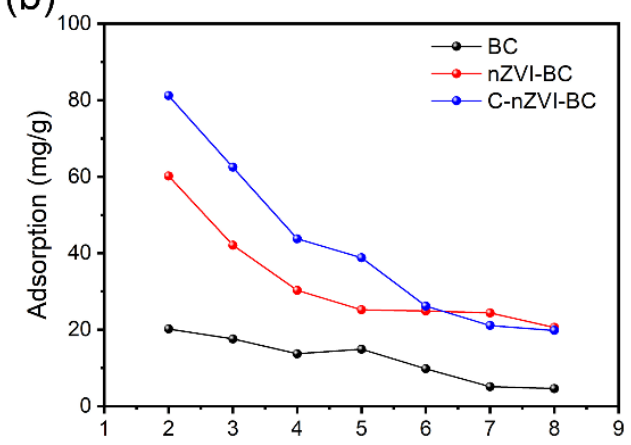

(d)

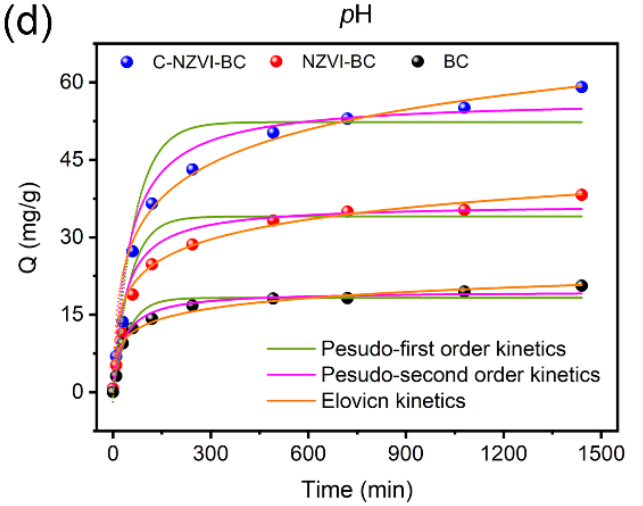

Figure 4. Sorption performance of hexavalent chromium $(\mathrm{Cr}(\mathrm{VI}))$ onto three adsorbents. Sorption rate and zeta potential of C-nZVI-BC in different $\mathrm{pH}$ solutions (a); effect of $\mathrm{pH}$ on the sorption of $\mathrm{Cr}(\mathrm{VI})$ onto adsorbents $\left(T=30^{\circ} \mathrm{C}, V=100 \mathrm{~mL}\right.$, weight of adsorbents $=100 \mathrm{mg}$, and initial $\mathrm{Cr}(\mathrm{VI})$ concentration $=100 \mathrm{mg} / \mathrm{L})(\mathbf{b}) ; \mathrm{Cr}(\mathrm{VI})$ sorption isotherms and fitting results (c); and $\mathrm{Cr}(\mathrm{VI})$ sorption kinetics and fitting results $(\mathbf{d})(\mathrm{pH}=2$, shaking for $24 \mathrm{~h})$.

\subsubsection{Effect of Ionic Strength and Temperature}

The sorption behavior of C-nZVI-BC was investigated in $\mathrm{Cr}(\mathrm{VI})$ solutions with varying $\mathrm{NaNO}_{3}$ concentrations. As shown in Figure S3, the sorption capacity of $\mathrm{Cr}(\mathrm{VI})$ gradually decreased from 82.5 to $26.19 \mathrm{mg} / \mathrm{g}$ with an increase of $\mathrm{NaNO}_{3}$ concentration from 0.005 to $5 \mathrm{M}$ at pH 2, indicating that high ionic strength impeded the $\mathrm{Cr}(\mathrm{VI})$ sorption. This was mainly because of competitive sorption of $\mathrm{NO}_{3}{ }^{-}$ and $\mathrm{Cr}(\mathrm{VI})$ ions on the $\mathrm{C}-\mathrm{nZVI}-\mathrm{BC}$ surface. The temperature effect on the sorption performance of C-nZVI-BC was investigated in $\mathrm{Cr}(\mathrm{VI})$ solutions, and the experiments were carried out at different temperatures $(298,308$, and $318 \mathrm{~K})$. As displayed in Figure S6, it was found that the maximal sorption capacity of $\mathrm{Cr}(\mathrm{VI})$ increased from 63.6 to $45.3 \mathrm{mg} / \mathrm{g}$ with an increase in temperature from 298 to $318 \mathrm{~K}$, suggesting the $\mathrm{Cr}(\mathrm{VI})$ removal process was an exothermic reaction by $\mathrm{C}-\mathrm{nZVI}-\mathrm{BC}$.

\subsection{Sorption Isotherms and Kinetic Study}

The sorption capacities of BC, nZVI-BC, and C-nZVI-BC were evaluated using Langmuir and Freundlich isotherm models. The corresponding results are presented in Figure $4 \mathrm{c}$ and Table S3. The results indicated that the sorption capacity increased with a high concentration of $\mathrm{Cr}(\mathrm{VI})$ until a plateau was reached (Figure 4c). Additionally, according to the correlation coefficient $\left(R^{2}\right)$ values (Table S3), the Langmuir model (0.994 for C-nZVI-BC, 0.998 for nZVI-BC, and 0.990 for BC) fit the experimental data better than the Freundlich model ( 0.959 for C-nZVI-BC, 0.926 for nZVI-BC, and 0.987 for $\mathrm{BC})$, indicating a monolayer sorption process $[45,46]$. According to the results of the Langmuir 
model simulation, the maximum sorption capacities of $\mathrm{Cr}(\mathrm{VI})$ were $18.258 \mathrm{mg} / \mathrm{g}$ for $\mathrm{BC}, 34.029 \mathrm{mg} / \mathrm{g}$ for nZVI-BC, and $52.304 \mathrm{mg} / \mathrm{g}$ for C-nZVI-BC.

The sorption rate was another consideration. The sorption kinetics of $\mathrm{Cr}(\mathrm{VI})$ on $\mathrm{BC}, \mathrm{nZVI}-\mathrm{BC}$, and C-nZVI-BC were investigated from 0 to $24 \mathrm{~h}$. As shown, the sorption rates increased rapidly within the initial $200 \mathrm{~min}$ and then slowly grew until a plateau (Figure $4 \mathrm{~d}$ ). The pseudo-first-order, pseudo-second-order, and Elovich models were applied to evaluate the sorption kinetics of $\mathrm{Cr}(\mathrm{VI})$ on BC, nZVI-BC, and C-nZVI-BC [47,48], and the corresponding results are presented in Figure 4d and Table S4. The results indicated that the pseudo-second-order model of adsorbents best fit the experimental data (Table S4), with a correlation coefficient $\left(R^{2}\right)$ of 0.986 for BC, 0.956 for nZVI-BC, and 0.947 for C-nZVI-BC. The equilibration sorption capacity was $14.62 \mathrm{mg} / \mathrm{g}$ for BC, $43.78 \mathrm{mg} / \mathrm{g}$ for nZVI-BC, and $66.12 \mathrm{mg} / \mathrm{g}$ for C-nZVI-BC. Kinetics results indicated that the rate-controlling step was a chemisorption process.

\subsection{Reusability of $C-n Z V I-B C$}

To evaluate the recyclability of C-nZVI-BC, which owned the highest sorption capacity among the three adsorbents, the regenerated C-nZVI-BC was applied into the next round of sorption for six cycles. As presented in Figure 5a, the removal efficiency of $\mathrm{Cr}(\mathrm{VI})$ gradually decreased with more recycling times, and it decreased from $82.2 \mathrm{mg} / \mathrm{g}$ in the first round to $43.1 \mathrm{mg} / \mathrm{g}$ in the sixth round, with an average loss of $\sim 7.8 \mathrm{mg} / \mathrm{g}$ per cycle. The sorption performance of $\mathrm{Cr}(\mathrm{VI})$ through regenerated C-nZVI-BC in the second cycle is shown in Figure 5b. Overall, the C-nZVI-BC composite exhibited reasonable recyclability and held great potential for practical applications.

(a)

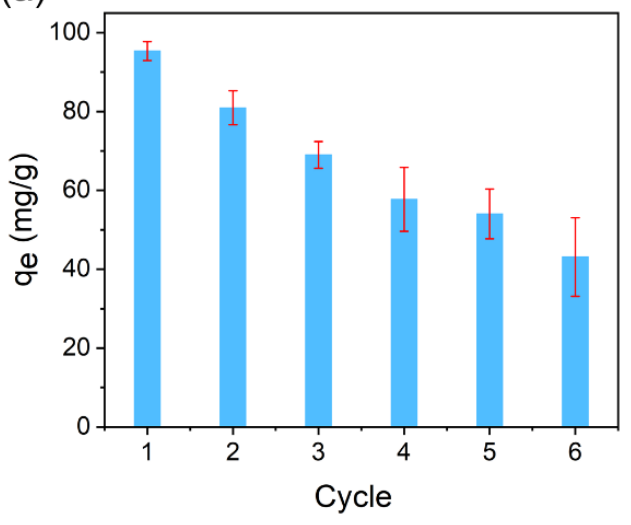

(b)

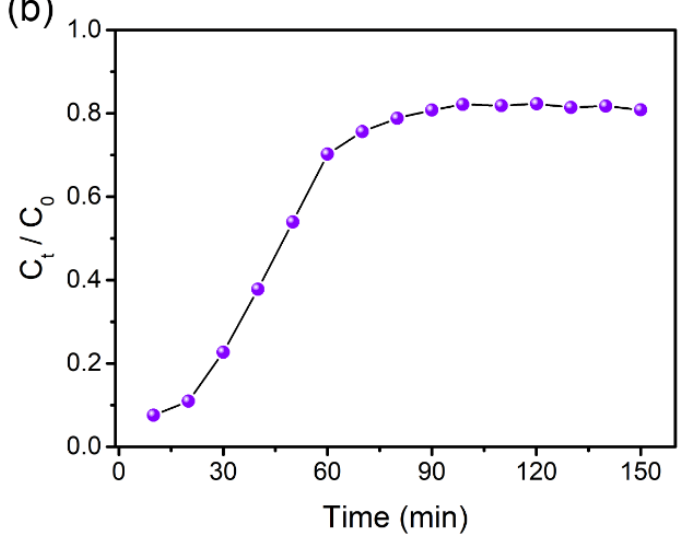

Figure 5. Six consecutive sorption-desorption cycles of $\mathrm{Cr}(\mathrm{VI})$ on $\mathrm{C}-\mathrm{nZVI}-\mathrm{BC}(\mathbf{a})$; sorption performance of $\mathrm{Cr}(\mathrm{VI})$ through regenerated $\mathrm{C}-\mathrm{nZVI}-\mathrm{BC}$ in the second cycle $(\mathbf{b})\left(C_{0}=100 \mathrm{mg} / \mathrm{L}, V=100 \mathrm{~mL}, t=6 \mathrm{~h}\right.$, $\mathrm{T}=30^{\circ} \mathrm{C}$ ).

\subsection{Sorption Mechanism}

SEM-EDS and X-ray photoelectron spectra were used to understand the chemical nature of nZVI-BC and C-nZVI-BC after sorption of Cr(VI). First, as presented in Figure 6, SEM images of nZVI-BC (Figure 6a) and C-nZVI-BC (Figure 6b) after sorption of $\mathrm{Cr}(\mathrm{VI})$ showed an irregular textural structure similar to that without $\mathrm{Cr}(\mathrm{VI})$ sorption (Figure $3 \mathrm{~b}, \mathrm{c})$. Element mapping was used to verify the presence and distribution of Cr elements over the nZVI-BC and C-nZVI-BC surfaces. The Cr distribution was uniform and continuous over the C-nZVI-BC surface (Figure 6d); however, several Cr element aggregate peaks were observed on the nZVI-BC surface, probably due to the aggregate particles of nZVI (Figure 6c). The above results confirmed the successful sorption of $\mathrm{Cr}(\mathrm{VI})$ ions on the nZVI-BC and C-nZVI-BC surfaces. 


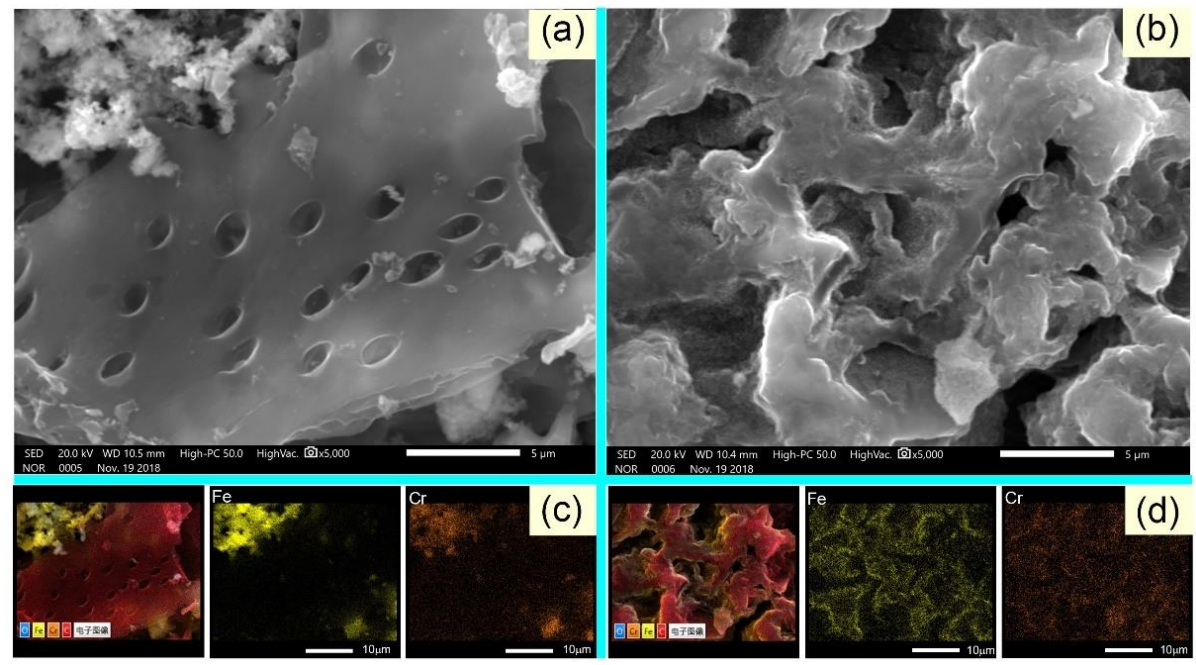

Figure 6. The SEM microscopic images of Cr(VI) adsorbed on nZVI-BC (a) and C-nZVI-BC (b). Scale bar $=5 \mu \mathrm{m}$. The energy-dispersive X-ray spectroscopy (EDS) element mapping of Fe (yellow) and $\mathrm{Cr}$ (golden) of the corresponding Cr(VI) adsorbed on nZVI-BC (c) and C-nZVI-BC (d). Scale bar: $10 \mu \mathrm{m}$.

Chemical states of the elements on the surface of nZVI-BC and C-nZVI-BC after the sorption of $\mathrm{Cr}(\mathrm{VI})$ were analyzed by XPS. Additional peaks at $577.4 \mathrm{eV}\left(\mathrm{Cr} 2 \mathrm{p}_{3 / 2}\right)$ and $587.4 \mathrm{eV}\left(\mathrm{Cr} 2 \mathrm{p}_{1 / 2}\right)$ were observed [27,29,33] (Figure S4) when spectra were compared to nZVI-BC and C-nZVI-BC without $\mathrm{Cr}(\mathrm{VI})$ sorption (Figure S2) [49,50], which corresponded to adsorbed $\mathrm{Cr}$ ions. The broad $\mathrm{Cr} 2 \mathrm{p}_{3 / 2}$ peak could be divided into two peaks at $579.18 \mathrm{eV}(\mathrm{Cr}(\mathrm{VI}))$ and $577.32 \mathrm{eV}(\mathrm{Cr}(\mathrm{III}))$ for nZVI-BC (Figure 7c) and $578.84 \mathrm{eV}(\mathrm{Cr}(\mathrm{VI}))$ and $576.85 \mathrm{eV}(\mathrm{Cr}(\mathrm{III}))$ for C-nZVI-BC (Figure 7d). Besides, deconvolution of the $\mathrm{Cr} 2 \mathrm{p}_{1 / 2}$ peak resulted in two components, included $590.7 \mathrm{eV}(\mathrm{Cr}(\mathrm{VI}))$ and $587.21 \mathrm{eV}(\mathrm{Cr}(\mathrm{III}))$ for nZVI-BC (Figure 7c) and $589.45 \mathrm{eV}(\mathrm{Cr}(\mathrm{VI}))$ and $587.01 \mathrm{eV}(\mathrm{Cr}(\mathrm{III}))$ for nZVI-BC (Figure 7d) (Table S6). Apparently, nZVI-BC and C-nZVI-BC not only provided sorption sites for $\mathrm{Cr}(\mathrm{VI})$, but also reduced $\mathrm{Cr}(\mathrm{VI})$ into $\mathrm{Cr}(\mathrm{III})$, mostly because of the role of nZVI. To further understand the difference between nZVI-BC and C-nZVI-BC in the sorption of $\mathrm{Cr}(\mathrm{VI})$ ions, the $\mathrm{O} 1 \mathrm{~s}$ and $\mathrm{Fe} 2 \mathrm{p}$ spectra of $\mathrm{Cr}(\mathrm{VI})$ adsorbed on nZVI-BC and C-nZVI-BC were analyzed. The high-resolution XPS O 1s spectra of nZVI-BC and $\mathrm{C}-\mathrm{nZVI}-\mathrm{BC}$ could be deconvoluted into three different oxygen-containing functional groups, respectively: (i) $\mathrm{O}-\mathrm{M}(\mathrm{H}, \mathrm{Fe}$, and $\mathrm{Cr}$ ) at $530.52 \mathrm{eV}$, (ii) $\mathrm{C}=\mathrm{O}$ at $531.65 \mathrm{eV}$, and (iii) $\mathrm{C}-\mathrm{O}-\mathrm{R}$ at $532.83 \mathrm{eV}$ for nZVI-BC (Figure 7a); and (i) M-O-M at $529.88 \mathrm{eV}$, (ii) $\mathrm{C}=\mathrm{O}$ at $531.15 \mathrm{eV}$, and (iii) $\mathrm{C}-\mathrm{O}-\mathrm{R}$ at $532.96 \mathrm{eV}$ for C-nZVI-BC (Figure 7b) [50,51]. The sorption mechanism of Cr(VI) on C-nZVI-BC was further studied because of the preeminent sorption performance. It was found that the peak intensity of metal O species was significantly increased in comparison to pure nZVI-BC and C-nZVI-BC (Figure 2e,f and Figure $7 \mathrm{a}, \mathrm{b})$, suggesting the formation of a bond between oxygen-containing groups and the $\mathrm{Cr}$ ion. Besides, shifts of the Fe 2p peaks from $706 \mathrm{eV}$ to $711 \mathrm{eV}$ were observed when they were compared to the spectrum of the pure C-nZVI-BC. Deconvolution of the Fe $2 p$ peaks gave excellent fittings and showed six components, that is, $\mathrm{Fe}_{2} \mathrm{O}_{3}$ at 711.85 and $724.60 \mathrm{eV}$, $\mathrm{FeO}$ at 715.13 and $727.65 \mathrm{eV}$, and $\mathrm{Fe}^{3+}$ satellites at 719.75 and $732.82 \mathrm{eV}$ (Figure $7 \mathrm{f}$ ) [40,41]. Collectively, the XPS results suggested that the sorption process of $\mathrm{Cr}(\mathrm{VI})$ onto $\mathrm{C}-\mathrm{nZVI}-\mathrm{BC}$ underwent the following steps: the coordination of $\mathrm{O}$ with $\mathrm{Cr}$ to form $\mathrm{Cr}-\mathrm{O}$ complexes and the reduction of $\mathrm{Cr}(\mathrm{VI})$ into $\mathrm{Cr}(\mathrm{III})$. Considering all of the evidence presented above, we herein propose four mechanisms for $\mathrm{Cr}(\mathrm{VI})$ sorption on the $\mathrm{C}-\mathrm{nZVI}-\mathrm{BC}$ surface (Figure 8), that is, complexation, precipitation, electrostatic interactions, and chemical reduction. 

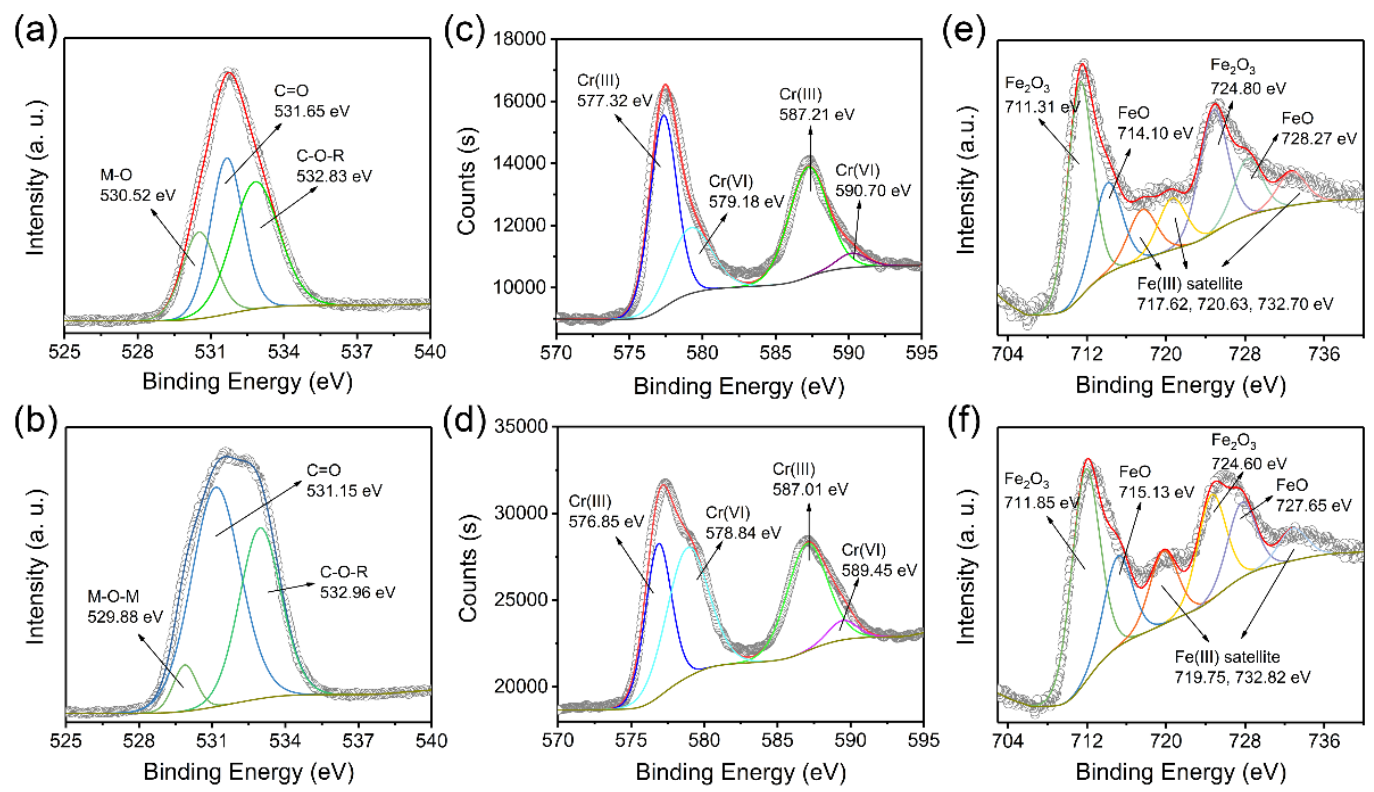

Figure 7. High-resolution XPS spectra of $\mathrm{O} 1 \mathrm{~s}, \mathrm{Cr} 2 \mathrm{p}$, and Fe 2p for $\mathrm{Cr}(\mathrm{VI})$ adsorbed on nZVI-BC (a,c,e) and C-nZVI-BC (b,d,f).

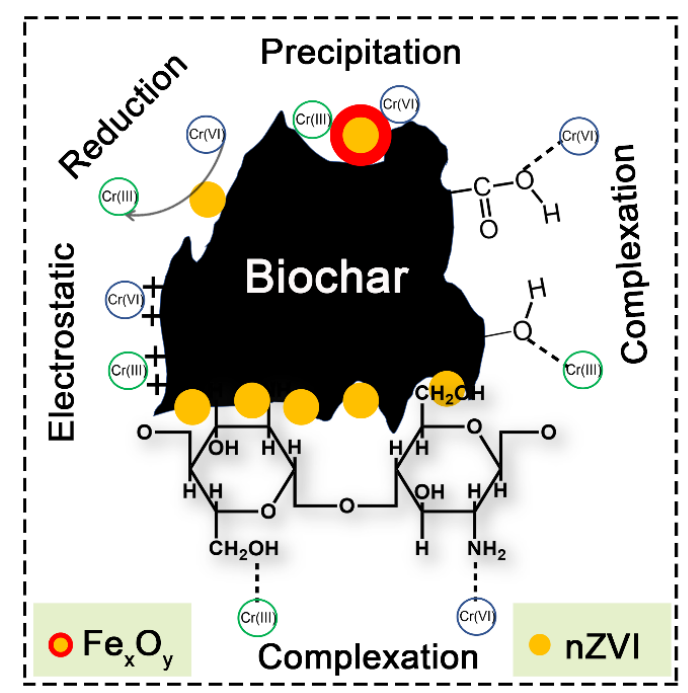

Figure 8. Mechanisms of $\mathrm{Cr}(\mathrm{VI})$ sorption by $\mathrm{C}-\mathrm{nZVI}-\mathrm{BC}$.

\section{Conclusions}

In summary, a low-cost and eco-friendly adsorbent with high sorption capacity was fabricated from E. crassipes biomass. Among BC, nZVI-BC, and C-nZVI-BC, C-nZVI-BC showed the best sorption performance. The maximum sorption capacity of $\mathrm{Cr}(\mathrm{VI})$ by $\mathrm{C}-\mathrm{nZVI}-\mathrm{BC}$ was $82.8 \mathrm{mg} / \mathrm{g}$ at $\mathrm{pH} 2$, much higher than pristine BC $(20.6 \mathrm{mg} / \mathrm{g})$ and nZVI-BC $(60.2 \mathrm{mg} / \mathrm{g})$. Additionally, the sorption capacity of $\mathrm{Cr}(\mathrm{VI})$ was increased at a lower $\mathrm{pH}$ and ionic strength. Batch $\mathrm{Cr}(\mathrm{VI})$ sorption experiments were well fitted by the Langmuir and pseudo-second-order kinetic models, suggesting a monolayer chemical sorption process for all three adsorbents. A reusability assay indicated that C-nZVI-BC could be reused for six cycles, and more than $43 \%$ sorption capacity was retained. The surface chemical nature of the $\mathrm{Cr}(\mathrm{VI})$-adsorbed C-nZVI-BC was investigated with XPS, suggesting four sorption mechanisms, i.e., complexation, precipitation, electrostatic interactions, and chemical reduction. This study, as a prototype demonstration, converted a biomass hazard in the environment into a highly efficient adsorbent, paving the road for future research on utilizing waste by considering environmental applications. 
Supplementary Materials: The following are available online at http://www.mdpi.com/1660-4601/16/17/3046/s1, Figure S1: Thermogravimetric curve; Figure S2: The XPS spectra; Figure S3: Effect of solubility of background solution $\left(\mathrm{NaNO}_{3}\right)$ on the $\mathrm{Cr}(\mathrm{VI})$ sorption by $\mathrm{C}-\mathrm{nZVI}-\mathrm{BC}$; Figure S4: The XPS survey spectra of nZVI-BC and C-nZVI-BC after Cr sorption; Figure S5: The EDX of the C-nZVI-BC composite before and after Cr(VI) sorption; Table S1: Statistical table of experimental variables and invariants; Table S2: Parameters characterizing the pore structure; Table S3: Isotherm parameters obtained by experimental data for the sorption of Cr(VI); Table S4: Kinetic parameters for the sorption of $\mathrm{Cr}(\mathrm{VI})$; Table S5: The elemental composition and atom percent of the C-nZVI-BC composite before and after $\mathrm{Cr}(\mathrm{VI})$ sorption.

Author Contributions: Conceptualization, X.-L.C., F.L., X.J.X., L.C.; methodology, X.-L.C., F.L., X.J.X., L.C.; investigation, X.-L.C., F.L., X.J.X., L.C.; data curation, X.-L.C., F.L., X.J.X., L.C.; writing-original draft preparation, X.-L.C.; writing-review and editing, X.-L.C., F.L., Z.L., L.C.; project administration, F.L.; funding acquisition, F.L.

Funding: This research was funded by the National Key Research and Development Program of China (Grant No. 2016YFC0402600); the National Natural Science Foundation of China (Grant No. 41001341); the water conservancy science and technology innovation project of Guangdong Province (Grant No. 2016-22,2017-21); the Joint Funding Research Project of Guangdong Province and the China Ministry of Education (Grant No. 2013B090500022); and the Science and Technology Planning Project of Dongguan City (Grant No. 2016108101015).

Acknowledgments: The authors greatly thank Jeremy Cao for help with language review during manuscript preparation.

Conflicts of Interest: The authors declare no conflicts of interest.

\section{Abbreviations}

$\begin{array}{ll}\text { E. crassipes } & \text { Eichhornia crassipes } \\ \text { C } & \text { Chitosan } \\ \text { nZVI } & \text { Nanoscale zero-valent iron } \\ \text { BC } & \text { Biochar }\end{array}$

\section{References}

1. Nriagu, J.O.; Nieboer, E. Chromium in the Natural and Human Environments; John Wiley and Sons: New York, NY, USA, 1988.

2. Huang, J.; Cao, Y.H.; Qin, B.H.; Zhong, G.; Zhang, J.; Yu, H.; Wang, H.J.; Peng, F. Highly efficient and acid-corrosion resistant nitrogen doped magnetic carbon nanotubes for the hexavalent chromium removal with subsequent reutilization. Chem. Eng. J. 2019, 361, 547-558. [CrossRef]

3. Zou, Y.; Wang, X.; Khan, A.; Wang, P.; Liu, Y.; Alsaedi, A.; Hayat, T.; Wang, X. Environmental remediation and application of nanoscale zero-valent iron and its composites for the removal of heavy metal ions: A review. Environ. Sci. Technol. 2016, 50, 7290-7304. [CrossRef] [PubMed]

4. Bhaumik, M.; Maity, A.; Srinivasu, V.V.; Onyango, M.S. Enhanced removal of Cr(VI) from aqueous solution using polypyrrole/ $\mathrm{Fe}_{3} \mathrm{O}_{4}$ magnetic nanocomposite. J. Hazard. Mater. 2011, 190, 381-390. [CrossRef] [PubMed]

5. Lyu, H.H.; Tang, J.C.; Huang, Y.; Gai, L.S.; Zeng, E.Y.; Liber, K.; Gong, Y.Y. Removal of hexavalent chromium from aqueous solutions by a novel biochar supported nanoscale iron sulfide composite. Chem. Eng. J. 2017, 322, 516-524. [CrossRef]

6. Nayak, V.; Jyothi, M.S.; Balakrishna, R.G.; Padaki, M.; Deon, S. Novel modified poly vinyl chloride blend membranes for removal of heavy metals from mixed ion feed sample. J. Hazard. Mater. 2017, 331, 289-299. [CrossRef] [PubMed]

7. Avila, M.; Burks, T.; Akhtar, F.; Gothelid, M.; Lansaker, P.C.; Toprak, M.S.; Muhammed, M.; Uheida, A. Surface functionalized nanofibers for the removal of chromium(VI) from aqueous solutions. Chem. Eng. J. 2014, 245, 201-209. [CrossRef]

8. Foo, K.Y.; Hameed, B.H. An overview of landfill leachate treatment via activated carbon adsorption process. J. Hazard. Mater. 2009, 171, 54-60. [CrossRef] [PubMed]

9. Uddin, M.K. A review on the adsorption of heavy metals by clay minerals with special focus on the past decade. Chem. Eng. J. 2017, 308, 438-462. [CrossRef] 
10. Herrero-Latorre, C.; Barciela-García, J.; García-Martín, S.; Pena-Crecente, R.M. Graphene and carbon nanotubes as solid phase extraction sorbents for the speciation of chromium: A review. Anal. Chim. Acta 2018, 1002, 1-17. [CrossRef]

11. Li, J.; Wang, X.X.; Zhao, G.; Chen, C.L.; Chai, Z.F.; Alsaedi, A.; Hayat, T.; Wan, X.K. Metal-organic framework-based materials: Superior adsorbents for the capture of toxic and radioactive metal ions. Chem. Soc. Rev. 2018, 47, 2322.

12. Inyang, M.I.; Gao, B.; Yao, Y.; Xue, Y.; Zimmerman, A.; Mosa, A.; Pullammanappallil, P.; Ok, Y.S.; Cao, X.D. A review of biochar as a low-cost adsorbent for aqueous heavy metal removal. Crit. Rev. Environ. Sci. Technol. 2016, 46, 406-433. [CrossRef]

13. Burakov, A.E.; Galunin, E.V.; Burakova, I.V.; Kucherova, A.E.; Agarwal, S.; Tkachev, A.G.; Gupta, V.K. Adsorption of heavy metals on conventional and nanostructured materials for wastewater treatment purposes: A review. Ecotox. Environ. Saf. 2018, 148, 702-712. [CrossRef]

14. Li, H.B.; Dong, X.L.; da Silva, E.B.; Oliveira, L.M.; Chen, Y.S.; Ma, L.N.Q. Mechanisms of metal sorption by biochars: Biochar characteristics and modifications. Chemosphere 2017, 178, 466-478. [CrossRef] [PubMed]

15. Qian, K.Z.; Kumar, A.; Zhang, H.L.; Bellmer, D.; Huhnke, R. Recent advances in utilization of biochar. Renew. Sustain. Energy Rev. 2015, 42, 1055-1064. [CrossRef]

16. Kong, H.; He, J.; Gao, Y.; Wu, H.; Zhu, X. Cosorption of phenanthrene and mercury (II) from aqueous solution by soybean stalk-based biochar. J. Agric. Food Chem. 2011, 59, 12116-12123. [CrossRef]

17. Lu, K.P.; Yang, X.; Gielen, G.; Bolan, N.; Ok, Y.S.; Niazi, N.K.; Xu, S.; Yuan, G.D.; Chen, X.; Zhang, X.K.; et al. Effect of bamboo and rice straw biochars on the mobility and redistribution of heavy metals $(\mathrm{Cd}, \mathrm{Cu}, \mathrm{Pb}$ and $\mathrm{Zn)} \mathrm{in} \mathrm{contaminated} \mathrm{soil.} \mathrm{J.} \mathrm{Environ.} \mathrm{Manag.} \mathrm{2017,} \mathrm{186,} \mathrm{285-292.} \mathrm{[CrossRef]} \mathrm{[PubMed]}$

18. Bashir, S.; Hussain, Q.; Akmal, M.; Riaz, M.; Hu, H.; Ijaz, S.S.; Iqbal, M.; Abro, S.; Mehmood, S.; Ahmad, M. Sugarcane bagasse-derived biochar reduces the cadmium and chromium bioavailability to mash bean and enhances the microbial activity in contaminated soil. J. Soil. Sediment. 2018, 18, 874-886. [CrossRef]

19. Patel, S. Threats, management and envisaged utilizations of aquatic weed Eichhornia crassipes: An overview. Rev. Environ. Sci. Bio Technol. 2012, 11, 249-259. [CrossRef]

20. Guna, V.; Ilangovan, M.M.; Anantha Prasad, G.; Reddy, N. Water Hyacinth: A Unique Source for Sustainable Materials and Products. ACS Sustain. Chem. Eng. 2017, 5, 4478-4490. [CrossRef]

21. Bai, F.; Chisholm, R.; Sang, W.; Dong, M. Spatial risk assessment of alien invasive plants in China. Environ. Sci. Technol. 2013, 47, 7624-7632. [CrossRef] [PubMed]

22. Zhang, F.; Wang, X.; Yin, D.X.; Peng, B.C.; Tan, Y.; Liu, Y.G.; Tan, X.F.; Wu, S.X. Efficiency and mechanisms of $\mathrm{Cd}$ removal from aqueous solution by biochar derived from water hyacinth (Eichornia crassipes). J. Environ. Manag. 2015, 153, 68-73. [CrossRef] [PubMed]

23. Li, F.; Shen, K.X.; Long, X.L.; Wen, J.S.; Xie, X.J.; Zeng, X.Y.; Liang, Y.Y.; Wei, Y.S.; Lin, Z.F.; Huang, W.R.; et al. Preparation and Characterization of Biochars from Eichornia crassipes for Cadmium Removal in Aqueous Solutions. PLoS ONE 2016, 11, e0148132. [CrossRef] [PubMed]

24. Chen, L.; Li, F.; Wei, Y.S.; Li, G.G.; Shen, K.X.; He, H.J. High cadmium adsorption on nanoscale zero-valent iron coated Eichhornia crassipes biochar. Environ. Chem. Lett. 2019, 17, 589-594. [CrossRef]

25. Xu, Y.; Liu, Y.G.; Liu, S.B.; Tan, X.F.; Zeng, G.M.; Zeng, W.; Ding, Y.; Cao, W.; Zheng, B.H. Enhanced adsorption of methylene blue by citric acid modification of biochar derived from water hyacinth (Eichornia crassipes). Environ. Sci. Pollut. Res. 2016, 23, 23606-23618. [CrossRef] [PubMed]

26. Chen, Y.Y.; Wang, B.Y.; Xin, J.; Sun, P.; Wu, D. Adsorption behavior and mechanism of Cr(VI) by modified biochar derived from Enteromorpha prolifera. Ecotox. Environ. Saf. 2018, 164, 440-447. [CrossRef] [PubMed]

27. Zhang, M.M.; Liu, Y.G.; Li, T.T.; Xu, W.H.; Zheng, B.H.; Tan, X.F.; Wang, H.; Guo, Y.M.; Guo, F.Y.; Wang, S.F. Chitosan modification of magnetic biochar produced from Eichhornia crassipes for enhanced sorption of Cr(VI) from aqueous solution. RSC Adv. 2015, 5, 46955-46964. [CrossRef]

28. Sun, Q.Z.; Saratale, R.G.; Saratale, G.D.; Kim, D.S. Pristine and modified radix Angelicae dahuricae (Baizhi) residue for the adsorption of methylene blue from aqueous solution: A comparative study. J. Mol. Liq. 2018, 265, 36-45. [CrossRef]

29. Zhang, S.; Lyu, H.H.; Tang, J.C.; Song, B.; Zhen, M.; Liu, X.M. A novel biochar supported CMC stabilized nano zero-valent iron composite for hexavalent chromium removal from water. Chemosphere 2019, 217, 686-694. [CrossRef] 
30. Gao, J.; Yang, L.Z.; Liu, Y.Y.; Shao, F.L.; Liao, Q.; Shang, J. Scavenging of Cr(VI) from aqueous solutions by sulfide-modified nanoscale zero-valent iron supported by biochar. J. Taiwan Inst. Chem. Eng. 2018, 91, 449-456. [CrossRef]

31. Toli, A.; Varouxaki, A.; Mystrioti, C.; Xenidis, A.; Papassiopi, N. Green Synthesis of Resin Supported Nanoiron and Evaluation of Efficiency for the Remediation of $\mathrm{Cr}(\mathrm{VI})$ Contaminated Groundwater by Batch Tests. Bull. Environ. Contam. Toxicol. 2018, 101, 711-717. [CrossRef]

32. Kołodyńska, D.; Wnçrzak, R.; Leahy, J.J.; Hayes, M.H.B.; Kwapiński, W.; Hubicki, Z. Kinetic and adsorptive characterization of biochar in metal ions removal. Chem. Eng. J. 2012, 197, 295-305. [CrossRef]

33. Hu, X.J.; Wang, J.S.; Liu, Y.G.; Li, X.; Zeng, G.M.; Bao, Z.L.; Zeng, X.X.; Chen, A.; Long, W.F. Adsorption of chromium (VI) by ethylenediamine-modified cross-linked magnetic chitosan resin: Isotherms, kinetics and thermodynamics. J. Hazard. Mater. 2011, 185, 306-314. [CrossRef] [PubMed]

34. Zhu, L.; Tong, L.H.; Zhao, N.; Li, J.; Lv, Y.Z. Coupling interaction between porous biochar and nano zero valent iron/nano $\alpha$-hydroxyl iron oxide improves the remediation efficiency of cadmium in aqueous solution. Chemosphere 2019, 219, 493-503. [CrossRef]

35. Georgieva, V.; Zvezdova, D.; Vlaev, L. Non-isothermal kinetics of thermal degradation of chitosan. Chem. Cent. J. 2012, 6, 81. [CrossRef] [PubMed]

36. Chen, L.; Tang, M.; Chen, C.; Chen, M.; Luo, K.; Xu, J.; Zhou, D.; Wu, F. Efficient bacterial inactivation by transition metal catalyzed auto-oxidation of sulfite. Environ. Sci. Technol. 2017, 51, 12663-12671. [CrossRef]

37. Jin, X.Y.; Zhuang, Z.C.; Yu, B.; Chen, Z.X.; Chen, Z.L. Functional chitosan-stabilized nanoscale zero-valent iron used to remove acid fuchsine with the assistance of ultrasound. Carbohydr. Polym. 2016, 136, 1085-1090. [CrossRef]

38. Zhou, Z.; Liu, Y.G.; Liu, S.B.; Liu, H.Y.; Zeng, G.M.; Tan, X.F.; Yang, C.P.; Ding, Y.; Yan, Z.L.; Cai, X.X. Sorption performance and mechanisms of arsenic(V) removal by magnetic gelatin-modified biochar. Chem. Eng. J. 2017, 314, 223-231. [CrossRef]

39. Mills, P.; Sullivan, J. A study of the core level electrons in iron and its three oxides by means of X-ray photoelectron spectroscopy. J. Phys. D Appl. Phys. 1983, 16, 723. [CrossRef]

40. Warwick, M.E.A.; Kaunisto, K.; Carraro, G.; Gasparotto, A.; Maccato, C.; Barreca, D. A Study of Pt/ $\alpha-\mathrm{Fe}_{2} \mathrm{O}_{3}$ Nanocomposites by XPS. Surf. Sci. Spectra 2015, 22, 47-57. [CrossRef]

41. Dewage, N.B.; Liyanage, A.S.; Pittman, C.U.; Mohan, D.; Mlsna, T. Fast nitrate and fluoride adsorption and magnetic separation from water on alpha- $\mathrm{Fe}_{2} \mathrm{O}_{3}$ and $\mathrm{Fe}_{3} \mathrm{O}_{4}$ dispersed on Douglas fir biochar. Bioresour. Technol. 2018, 263, 258-265. [CrossRef]

42. Hawn, D.D.; de Koven, B.M. Deconvolution as a correction for photoelectron inelastic energy losses in the core level XPS spectra of iron oxides. Surf. Interface Anal. 1987, 10, 63-74. [CrossRef]

43. Yan, Q.G.; Wan, C.; Liu, X.J.; Gao, J.S.; Yu, F.J.; Zhang, L.; Cai, Z.Y. Iron nanoparticles in situ encapsulated in biochar-based carbon as an effective catalyst for the conversion of biomass-derived syngas to liquid hydrocarbons. Green Chem. 2013, 15, 1631. [CrossRef]

44. Dong, X.L.; Ma, L.N.Q.; Li, Y.C. Characteristics and mechanisms of hexavalent chromium removal by biochar from sugar beet tailing. J. Hazard. Mater. 2011, 190, 909-915. [CrossRef]

45. Wang, F.; Liu, L.Y.; Liu, F.; Wang, L.G.; Ouyang, T.; Chang, C.T. Facile one-step synthesis of magnetically modified biochar with enhanced removal capacity for hexavalent chromium from aqueous solution. J. Taiwan Inst. Chem. Eng. 2017, 81, 414-418. [CrossRef]

46. Park, J.H.; Ok, Y.S.; Kim, S.H.; Cho, J.S.; Heo, J.S.; Delaune, R.D.; Seo, D.C. Competitive adsorption of heavy metals onto sesame straw biochar in aqueous solutions. Chemosphere 2016, 142, 77-83. [CrossRef] [PubMed]

47. Wang, S.; Gao, B.; Li, Y.; Creamer, A.E.; He, F. Adsorptive removal of arsenate from aqueous solutions by biochar supported zero-valent iron nanocomposite: Batch and continuous flow tests. J. Hazard. Mater. 2017, 322, 172-181. [CrossRef] [PubMed]

48. Shi, Y.J.; Zhang, T.H.; Ren, Q.; Kruse, A.; Cui, R.F. Polyethylene imine modified hydrochar adsorption for chromium (VI) and nickel (II) removal from aqueous solution. Bioresour. Technol. 2018, 247, 370-379. [CrossRef]

49. Liu, Q.S.; Li, Y.J. Sorption and Reduction of Hexavalent Chromium from Aqueous Solutions by Surface Modified Biochars. Sep. Sci. Technol. 2015, 50, 2617-2624. [CrossRef] 
50. Luo, H.Y.; Lin, Q.T.; Zhang, X.F.; Huang, Z.F.; Liu, S.S.; Jiang, J.R.; Xiao, R.B.; Liao, X.Y. New insights into the formation and transformation of active species in $\mathrm{nZVI} / \mathrm{BC}$ activated persulfate in alkaline solutions. Chem. Eng. J. 2019, 359, 1215-1223. [CrossRef]

51. Lin, L.; Zhang, G.G.; Liu, X.W.; Khan, Z.H.; Qiu, W.W.; Song, Z.G. Synthesis and adsorption of Fe-Mn-La-impregnated biochar composite as an adsorbent for As(III) removal from aqueous solutions. Environ. Pollut. 2019, 247, 128-135. [CrossRef] [PubMed]

(C) 2019 by the authors. Licensee MDPI, Basel, Switzerland. This article is an open access article distributed under the terms and conditions of the Creative Commons Attribution (CC BY) license (http://creativecommons.org/licenses/by/4.0/). 